\title{
Chapter 7 \\ Laboratory Rotterdam. Logics of Exceptionalism in the Governing of Urban Populations
}

\author{
Friso van Houdt and Willem Schinkel
}

\subsection{Rotterdam as 'Policy Laboratory'}

For some time now, Rotterdam has actively portrayed itself as a policy laboratory. This laboratorial rhetoric, as one could call it, has prevailed in the fields of housing, urban problems and welfare provision, and most recently it has also emerged in the context of Rotterdam as a 'smart city'. The latter is nothing special, as technological applications to urban problems are full of 'urban labs', of experimentation and of what Halpern et al. (2013) have called 'test-bed urbanism'. However, in the context of urban and social policies in a very general sense, it is less common today. To understand the development of governing diversity in Rotterdam, it is pertinent to scrutinize the character and historical roots of Rotterdam's laboratorial logic.

The consideration of the city as a laboratory goes back to the Chicago School, many of whose foremost sociologists considered Chicago a laboratory. While they productively wavered between regarding the city as a field site (in which reality was found) and a laboratory (in which reality was made) (Gieryn 2006), the use of a laboratorial rhetoric by policy makers and politicians is of another kind. It is first and foremost a governing rhetoric, which explicitly assumes that urban reality can be made because it is found to be in a certain, more often than not deplorable, state. In Rotterdam, the laboratorial rhetoric has been associated with the 'innovative' character of policies regarding crime, urban segregation and poverty (Noordegraaf 2008). In no small measure, the 'innovative' nature of, for instance, combinations of care and control in social policies have been applauded by scientists (Notten 2008; Tops 2011).

\footnotetext{
F. van Houdt (ه)

Erasmus University College, Rotterdam, The Netherlands

e-mail: vanhoudt@euc.eur.nl

W. Schinkel

Erasmus University Rotterdam, Rotterdam, The Netherlands

e-mail: schinkel@essb.eur.nl 
As we argue, a laboratorial logic allows the assumption that one can start with a tabula rasa, that the ground has been cleared and a new, artificial arrangement of actors and objects is possible. A policy laboratory is a site at which this continuous starting anew in which the city becomes an experiment is enacted in ever new ways. This involves a particular way of dealing with history that is, itself, highly historically conditioned. It involves, on the one hand, the complete denegation of history, the putting history between brackets and, on the basis of a clear(ed) ground, start anew, as in a laboratory. On the other hand, this laboratorial rhetoric is legitimated on the basis of a very specific mobilization of history in the form of a traumatic memory: the bombing of Rotterdam by the Nazis in World War II. In order to properly situate the laboratorial rhetoric in urban and social policies in Rotterdam, and in order to tease out the political import of that rhetoric, we turn first to the historical narrative that supports it.

\subsection{Clearing the Ground: Historical Roots of the Laboratorial Rhetoric}

In 1946, the Dutch architect Van Embden said, in a comment on the bombing of the inner city by the Nazis on May 14, 1940:

\footnotetext{
Do you realize, Rotterdammer, that many of the most precious memories to what was lost in the days of May actually cling to what, rationally considered, were mere deficits of our old city? (...) The big fire has cleaned up with one blow what we, Rotterdamers, previously could or would not clear, however little it was in tune with the material demands of the present (...) We owe it to ourselves and to the future to seek out the most perfect, effective and characteristic form for everything we create, in order to give the utmost freedom to present life, now that it has been violently liberated from the shackles of the past. (quoted in Schuyt and Taverne 2000: 177-178)
}

The idea that the bombing of Rotterdam is here considered to have, in one particular sense at least, 'liberated' the city is striking in this quote. It can only be understood in light of the modernist urban planning of the age, which had drafted elaborate plans for the modernization of Rotterdam prior to the war. Some of these were under way, but many were as yet unimplemented due to the fact that the old city of Rotterdam still stood. So while Rotterdam was already celebrated for its modernist architecture in the 1930s (Van Ulzen 2007), it had not entirely developed its inner city according to modernist recipes. For a long time, the city centre had consisted of narrow streets with small houses along them in areas that would nowadays be characterized as slums. In the early twentieth century some of these had already been demolished (cf. Van Ulzen 2007; Van der Woud 2010). In one sense, then, the bombing of Rotterdam has merely sped up a process that was already in development. This became clear when the rubble was to be cleared and the question was to be answered what to keep and what to tear down. The planners opted for the new urban planning that had, already in the 1930s, displayed a preference for motorways and high-rise, and hence much more was torn down than was strictly speaking 
necessary. The so-called 'basic plan' (Basisplan) for the redevelopment of Rotterdam in 1946 thus entailed a new round of demolition, the first being the bombing and its immediate consequences (Wagenaar 1992: 308, quoted in: Rooijendijk 2005: 182). This new round of demolition cleared the way for the modernist reconstruction of the city - a reconstruction that was therefore precisely not a reconstruction. The bombing and the ensuing fire were thus mobilized as an opportunity to implement the type of urban planning that was already popular among modernist planners and architects such as Oud and Van Traa. The bombing and the subsequent demolition offered the key ingredients of the modernist city: clarity, space, and relative emptiness in the city centre. So while city planner Witteveen had suggested to reconstruct the old city in his plan of the Advisory Council Urban Plan Rotterdam (1941), the prevailing current was towards the modernist city of the Basisplan of Van Traa. This largely excluded the city centre from housing, which was indeed, after the reconstruction, much less prevalent in the centre than before the war. Schuyt and Taverne (2000: 178) therefore speak of a sense of a 'double bombardment' that lived among critics of modernist architecture.

In order to understand the relation between current laboratorial rhetoric and the idea of a tabula rasa, it is pertinent to consider the governing technique deployed after the war. The land affected by the bombing and the fire was collectively dispossessed. This led to the fact that, again according to Schuyt and Taverne, "the city was ready to be built for the future, but it was at the same time robbed of its memory and its history" (Schuyt and Taverne 2000: 25). And this has been a persistent feature of the official governmental imagination of the city. The memory of Rotterdam revolves around the 'lost heart' of the city, a reference to the sculpture the artist Ossip Zadkine made for the city after having taken a train through the then empty (demolished) city centre. This memory of loss, this trauma, is thus the memory of $a$ loss of memory. It is also a historical narrative that, paradoxically, continues to posit the city as ahistorical. The rhetoric of the 'loss of the city's heart' has continued to inform urban planning and policies. When the Basisplan was presented, in 1946, in the form of a booklet to inform the larger public, this book was called The new heart of Rotterdam (Van Traa 1946). But in fact, the city still puts up big plaques whenever construction is going on that say 'Hear the new heart of Rotterdam pounding here!'

\subsection{Enjoying One's Trauma: Rendering the Past Productive}

The new modernist city of course encountered its fair share of criticism. Interestingly, that criticism often used the very discursive ploy that had made the modernist city possible, that of the 'missing heart' of Rotterdam. Jan Schaper's film City without heart (1966), for instance, is an indictment against the emptiness that characterized the city centre and that was typical of the modernist separation of urban functions. Ever since the war, then, the trope of the 'city without a heart' has been recurring, and it has supported efforts to change the city in contradictory ways. It has, then, 
assumed a strategic role in the discursive imagination of the city that continues to inform Rotterdam's urban and social policies. One could say that Rotterdam holds history hostage: it continues to assert that it has lost its heart, even though its city centre has been rebuilt and redone a number of times. The very idea of a cleared ground continues to legitimate new transformations. The supposed 'emptiness' at the heart of Rotterdam, provides the city's government with a maximum amount of flexibility. At each moment one can assume, for governing purposes, that the ground has been cleared and that one can hence engage in experimentation in the Rotterdam laboratory.

Rotterdam thus productively deploys its selective rendition of the past in new restructuring projects, in urban redevelopment plans that often constitute forms of gentrification openly so-called, and in urban policies. The assumed absence of the city's heart legitimates continued interventions both in the urban environment and in the urban population. Rotterdam, in other words, enjoys its war trauma, at least to the extent that its key governmental actors continue to deploy it to govern the city and its population. This is where the governing of diversity becomes visible. For what kind of city is imagined by the city's governmental actors? As Marguerite van den Berg has illustrated, Rotterdam is enmeshed in the transition from an industrial to a post-industrial city. This involves a shift in what she calls the urban 'mythology' (Van den Berg 2012). The urban government wishes to shed the image of the rough, male harbour worker, which no longer chimes with its labour market, and promote instead the more feminine and 'sexy' image of what it calls in its plans for 2008-2030 (Binnenstadsplan 2008-2030) the 'city lounge' (Bureau Binnenstad Rotterdam 2008). That, too, is in a sense the continuation of the emptiness that characterizes the city centre: in the city centre comes the lounge, the site for aimless hanging around. A city that puts a lot of effort in countering kids loitering, the cynical ideal of the city centre is that of a 'city lounge'.

Van den Berg's analysis illustrated clearly how the governing of Rotterdam in fact consists of the permanent problematization of its population. Of course, all government consists of problematizations, categorizations and orderings of heterogeneous populations (Chatterjee 2004). In Rotterdam, in particular, diversity is a key operator of governmental problematization. The Rotterdam population is considered either as too little 'integrated', or as too poor and lowly educated. Both are proxies for ethno-racial distinctions. Against them, a 'middle-class' is hoped to be attracted to the city, and this middle-class, in turn, is a proxy for white, 'autochthonous', higher educated citizens. In the last decade, such problematizations have been accompanied by large-scale government-led gentrification projects that have been described as a typical Rotterdam inflection of urban revanchism (Uitermark and Duyvendak 2006; Van den Berg 2013). One prime example of such gentrification has been the 'renewal' of Katendrecht, an area located at the harbour and a place in with a history of both prostitution, catering to workers in the harbour, and of migration. It has become one of the popular areas in Rotterdam, and this has 
involved a white-washing of the area through state-led gentrification. Such gentrification, and the urban imaginary that accompanies it, involves telling current residents of Rotterdam that they are, in one way or another, not good enough. Whoever reads the municipality's 'urban vision' for 2030 (Stadsvisie 2030), with its open embrace of the critically intended concept of gentrification (Rotterdam Municipality 2007), cannot but conclude that the city government wishes itself a different population. For some time now, this has been the case because of a sense of emergency. The clearing of the ground, the radical policy experimentation that oftentimes skims the boundaries of the legally tolerable and frequently proudly transgresses those boundaries, can be performed on the basis of an appeal to emergency. This 'state of emergency' has conventionally been constructed by referring to the 'type and characteristics of the population' of Rotterdam. It has been suggested, for instance, that Rotterdam would have to bar low-income families from certain neighbourhoods because these neighbourhoods could 'take no more'. Such measures, which were first experimented within laboratory Rotterdam, later became national law in the form of what tellingly became colloquially known as 'the Rotterdam Law'. The official name of the law, however, is the 'Umbrella and Exception Law', which makes the role of the exception explicit. In the appeal to emergency, a governing through exceptionalism becomes apparent that is a key feature of the way diversity has been an object of concern in Rotterdam.

\subsection{The Rotterdam Law}

The 2005 Umbrella and Exception Law is commonly known as "The Rotterdam Law". ${ }^{1}$ It consists of a configuration of governmental techniques aimed at the governing of 'excessive urban problems' through the regulation of the socio-economic (and thus also primarily ethnic) make-up of the population in certain areas. It primarily consists of measures aimed at restricting the influx of low-income populations ('kansarmen') to certain 'multi-problem areas' ('probleemwijken'). Based on a problem analysis of the number of poor people expected to live in Rotterdam in the future (Van Eijk 2010), specific exceptional zones are created allowing for an income-based exclusion of citizens living in the Rotterdam region for less than 6 years. A recent initiative (to be enacted on 1/1/2017) expands the reach of the Rotterdam Law by making it possible to reject 'asocial', 'criminal' and 'radicalized' citizens primarily based on police files. Newcomers are screened by the Mayor's office before they are allowed to settle in these so called exceptional zones as residents. A track-record of (sometimes non-verified police records of) crime, nuisance (e.g. intimidation, public intoxication), violence, radical religious thoughts may be used as a basis for rejection, and, in addition, a certificate of good conduct ('verklaring omtrent gedrag') may be requested.

\footnotetext{
${ }^{1} \mathrm{http}: / /$ wetten.overheid.nl/BWBR0019388/2015-01-01
} 


\subsection{Governing Through Exceptionalism}

Another good example of a governing through exceptionalism is the functioning of so-called 'Intervention Teams' in Rotterdam. For instance with the help of the Rotterdam Safety Index, neighbourhoods are selected where teams of different officials make house calls, often in highly intrusive ways that have been challenged by the Rotterdam Ombudsman as early as 2007 (Rotterdam Ombudsman 2007). Intervention Teams have existed in different forms, and they have had various foci, ranging from combating 'illegal habitation' and 'pot plantations' to providing assistance in debt relief or dealing with neighborly nuisance. In many cases, as described more in detail in Schinkel and Van den berg (2011), they have used highly invasive tactics to enter homes, thereby in practice suspending the rights of inhabitants. This happens predominantly in neighbourhoods where large numbers of so-called 'nonWestern allochtones' reside. Hence, those who do not fit the norm of a 'middleclass' population are more likely to have their rights suspended. The figure of the homo sacer, described by Agamben (1998), thus involves a flexible, temporo-spatial way of differentiating between parts of a population. It curtails some rights of some people in certain areas of the city and for some time. In the same way, preventive body searches have been carried out in specific neighbourhoods and in highly racialized ways, since the neighbourhoods targeted are, again, the parts of the city where relatively little 'middle-class' (read: white affluent) citizens reside.

This type of governing through exceptionalism is closely tied to the laboratorial rhetoric of Rotterdam policies. It appears in the form of a continuous clearing of the ground in conjunction with an appeal to emergency. The emergency lies in the severity of the 'problems', the truly problematic nature of the population, and this is therefore a highly biopolitical problematization as it involves the direct problematization of a population that is also the object of governmental intervention (literally, for instance, by 'Intervention Teams'). This 'state of emergency' can both legitimize the laboratorial clearing of the ground and be equated with the fact that in Rotterdam, the ground is still clear, the proper heart is still not beating. Here, too, biopolitics rings loud, since the collective has a 'heart' that is currently missing. Ever since the war, then, the state of emergency has been present, since the ground has always remained cleared and the heart has never started beating. And vice versa, whenever governmental problematizations are to be followed by biopolitical interventions, one can do so without recourse to rights or history, because, after all, in Rotterdam the ground has been cleared and a laboratorial situation of artificially starting-anew can be plausibly put forward.

The political character of a laboratorial mode of governing is thus that it foregrounds the exception. A laboratory involves an artificial cordoning off of objects and their relations. It exempts these from the larger relational networks in which they are enmeshed, as well as (and this is particularly relevant here) from the historical relations as a consequence of which they emerge. The exception is often a legal exception, and it is also a political exception. Because, in terms of accountability, the emergency and urgency of the policy situation allow for laboratorial policies, for 
policy experiments that cover new ground, often in semi-legal ways. And as with all laboratory experiments, they can't really fail because negative outcomes are outcomes nonetheless. When urban politics assumes the laboratorial mode of governing, then, it operates largely beyond the confines of democratic politics and it coincides with a biopolitical program. In the last decade or so, policies in Rotterdam have therefore been accompanied by a rhetoric of exceptionalism, which, tellingly, is often bellicose. The Intervention Teams have for a long time operated in Hotspot Zones; one type of Intervention Teams was coordinated by the 'Bureau Frontline', a supposedly extra-bureaucratic and in that sense exceptional entity within the municipality; there are 'City Marines' active, which have exceptional discretionary powers; there are 'frontline workers', which is a recoding of people involved in policy implementation' and there has been a 'reconquering' of the city.

The role of the exception has been noted to be typical of neoliberal forms of governing (Ong 2006; Easterling 2014). It renders spaces attractive for capitalization by producing them as highly flexible. Selectively suspending legal restrictions is key in the many 'zones' that have become preferred sites in the neoliberal management of goods and capital. As we argue in the next section, neoliberalism is a mode of governing that is operative in Rotterdam's laboratorial exceptionalism as well. And yet it is not adequately described by neoliberalism alone. One example of the neoliberal nature of the problematization of Rotterdam's population by its policy makers is the rationale behind 'Bureau Frontline'. It operates, according to its 'mission' statement, by starting with 'the Problem': "residents in backward neighbourhoods (achterstandswijken) have too little skills and cultural capital. This leads to stress and disfunctioning." 2 In other words: the problematization of certain parts of the population is framed in terms of their own deficits, and these deficits are construed, in Bourdieusian terms (although he would have cringed at the thought), of cultural and not economic capital. In typical neoliberal fashion, then, social problems are reduced to the deficits of individuals. Yet this individualizing politics is coupled in Rotterdam (and elsewhere) by a highly communitarian logic. In the next section, we illustrate how Rotterdam can be best understood by considering what we have called the neoliberal communitarian governing of populations that is situated in-between the promotion of the neoliberal, responsible and active subject and the coming community.

\subsection{Neoliberal Communitarianism: Governing Through Paradox}

The discourse of emergency dominated both the 2002 local election campaigns and subsequent programs of government (e.g., Rotterdam City Council 2002, 2003, 2006a, b). In 2002 and for the first time in the history of Rotterdam the labour party

\footnotetext{
${ }^{2}$ http://www.bureaufrontlijn.nl/ditzijnwe/missie/ (accessed 10 June 2016).
} 
(PvdA) was forced into opposition. A government coalition emerged that consisted of the liberal party (VVD), Christian democrats (CDA) and the winner of the elections (the political party of populist maverick politician Fortuyn) Liveable Rotterdam (LR) (from 0 to win 17 out of 45 seats) (see also Van Ostaaijen). It was this coalition that forged a new and paradoxical formulae of governing the city that can be called neoliberal communitarianism, a strategy that has been dominant even after new coalitions took over (see, for example, Rotterdam City Council 2006a, b).

Many scholars argue that neoliberalism is the dominant contemporary governmentality (Dean 2010: 176). Studies of governmentality regard neoliberalism as a political rationality of governing citizens (ourselves, others and the state) in relation to the truths and techniques of the market. Neoliberalism is both a critique and program of government (Foucault 2008). It is a critique of governing too much (specifically of welfarism). Neoliberalism hereby extends the economic gaze in two ways. First, previously non-economic domains or phenomena (such as crime, immigrant integration, social policy, healthcare, marriage and reproduction - including genetics) are now considered from an economic perspective (e.g., in terms of effects on human capital). Secondly, an economic filter or economic tribunal is applied to all the activities and interventions of public authorities and the state (i.e., a big program of purification that scrutinizes intervention in terms of costs, efficiency, abuse and excess) (Foucault 2008).

In addition, neoliberalism is also a program of governing aimed at the construction of the Enterprise City. This involves both the facilitation of existing markets and corresponding techniques: competition, accountability and the active construction of markets where they were previously non-existent. Neoliberalism also implies a specific conception of the citizen-subject as entrepreneur, as an active, responsible and rational subject. As such, citizens are relinked to governing networks in different ways. This all comes together in the neoliberal technique of responsibilization. For example, state interventions are considered too costly, ineffective, and inefficient and, therefore, citizens are urged to take responsibility for governing problems themselves or in coproduction with other actors, including the state. That is why 'active citizenship' can be considered a neoliberal technique of governing the present (Dean 2010).

But neoliberalism is also associated with New Public Management (NPM) which is indicated by the increasing use of performance indicators, the publication of outcomes and accountability. Moreover, neoliberalism may involve 'zero tolerance' crime policies, the extension of punishment (the sovereign fist), a criminalization of 'non-middle-class conduct' and the teaching of bourgeois virtues (discipline). Neoliberalism thus involves a specific reconfiguration of the triangle of sovereignty, discipline and government (power) based on an economic knowledge (truth) and a specific conceptualization of the rational, responsible and entrepreneurial citizen (subject) (Van Houdt 2014).

Some scholars argue (implicitly or explicitly) that neoliberalism is the sole dominant contemporary political rationality, and the case of Rotterdam is often presented as an illustration of the European road towards neoliberalism (e.g., Wacquant 2009). Others argue that neoliberalism often occurs in a combination with neo-conservatism 
(e.g., Brown 2006). We argue that the Rotterdam case is illustrative of a strategy of governing that combines the main features of neoliberal governmentality with those of governmental communitarianism. Their coming together is captured by the concept of neoliberal communitarianism. Indeed, the local government of citizens and social problems in Rotterdam is often framed in terms and techniques typical of neoliberalism (see above). But in addition, it is also considered in terms of a political rationality stressing the community, social cohesion, norms and values, the reciprocity of rights and duties (Rotterdam City Council 2002, 2003, 2006a, b; cf. Van Houdt and Schinkel 2014; Schinkel and Van Houdt 2010a, b). In other words, the neoliberal logic of governing citizens in Rotterdam which is present, for example, in fields ranging from housing policy to crime and immigrant integration is both challenged and complemented by a communitarian logic (cf. Van Swaaningen 2008).

Communitarianism, like neoliberalism, is not simply a political philosophy but a specific political rationality of governing (Delanty 2002). Communitarian governmentality aims to secure space for the community, for notions of care and belonging, but it also aims to restore morality, norms and values and a sense of responsibility as fundaments of citizenship, the family, and identity. Though communitarianism is often presented as the contender of neoliberalism (which it often is) the following remarks can be made. First, while in political theory and political philosophy analytical clarity is valued and contradiction considered an abomination, at the ground level of problematization and problems solving, that is, at the messy site of local policy making and political struggle (including compromise), opposing political rationalities may be easily combined into a strategy (the often non-subjective, nonintentional and often paradoxical forms) of governing. Secondly, neoliberalism and communitarianism find common ground in their shared critique of welfarism (sometimes associated with the old Labour Party). Thirdly, as will be described below, both political rationalities may support the same techniques of governing, albeit from a different logic.

Like neoliberalism, communitarianism also involves a reconfiguration of power and techniques of intervention (Van Houdt and Schinkel 2013). In terms of government, the community can be regarded as (capable of) self-governing, thereby, for example, delegating state responsibilities to active citizens. Like neoliberalism, communitarianism also uses the concept of 'active citizenship' and voluntary associations. But communitarianism may also involve disciplinary programs aimed to moralize citizens considered to be lagging behind in terms of the proper Dutch norms and values of the virtuous Dutch community (see 'The Rotterdam Code' below). Hence, one important technique of this governmental communitarianism is the moralization of social problems and the re-moralization of subjects ('ethical reconstruction') to the virtuous community (Rose 2000: 1407). Moreover, the tough side of communitarianism becomes visible in its heavy investment in sovereign techniques (incarceration, selective incapacitation, banishment) to protect the community against its various enemies (e.g., 'hardcore criminals', 'psychopath predators roaming the streets', 'non-western immigrants') (Van Houdt and Schinkel 2013). A good illustration of the moralizing logic of 'governmental communitarianism' (Delanty 2002) is “The Rotterdam Code". 


\subsection{The Rotterdam Code}

The Rotterdam Code is a policy document that explicitly deals with the problematization of super diversity in terms of crime and safety, lack of social cohesion, welfare dependency and unemployment. The Rotterdam Code starts with a question: 'When is an urban society really/truly a society?' The answer: 'When citizens take responsibility for themselves and their city. When they share certain norms and values, respect each other, work together and, when the livability of the city is under threat, correct and discipline each other.' (Rotterdam City Council 2006a, b: 2). It further states the code that

We Citizens of Rotterdam:

1. assume responsibility for our city and for each other; we do not discriminate

2. use Dutch as our common language;

3. do not accept radicalization and extremism;

4. raise our children to be full citizens;

5. treat women equally to men and with respect;

6. treat homosexuals equally to heterosexuals and with respect;

7. treat people of (different) religious conviction and people without conviction equally and with respect

This code can be summarized as follows: a real society consists of moral citizens and moral citizens 'participate in society' (Rotterdam City Council: 2006a, b). What is interesting here is the distinction made between a 'real society' and its negative other. A true society is inhabited by active citizens (moral citizens), it is, therefore, a moral space which is separated from communities inhabited by amoral and inactive citizens. In the proper society citizens govern themselves, are responsible, do not discriminate whereas in the realm outside this society people lack such dispositions. The true community consists of citizens speaking and thinking in Dutch. The other society consists of people communicating in a foreign language, they are extremists, while the moral citizens of the real society are intolerant to extremism and radicalism. In the real society women and homosexuals are considered equal to men and heterosexuals and they are all respected whereas in the amoral society a distinction in treatment is made between women/men and homosexuals/ heterosexuals (in addition, the former are also disrespected). In the deviant society, people with different religious convictions and people without a religious conviction are disrespected and treated unequally, whereas in the real society citizens with a different worldview or without religious conviction are treated equally and with respect. Hence, the 'moral citizen' is the 'normal subject' of the 'moral community'. Moral citizenship thus functions as technique of social closure (inclusion and exclusion). Included in society are the moral citizens who take responsibility for society and, as a consequence, excluded from this moral space are people who are not properly participating. Thus, 'society' is defining itself as a moral space and its norms become articulated, for example, as "in this moral space Dutch is the common language". Hence, if you are not capable of communicating in Dutch then you do not belong to the moral space of society because you are not participating correctly and therefore you are not a real citizen. 
So, who are the citizens standing/placed outside the real society because they are lacking moral citizenship, in other words, who are the people not associated with moral citizenship? At a more abstract level and in common terms it can be argued that people who are not 'integrated' reside outside the true moral community ("immigrants", “criminals", "mad", "unemployed" etc.) (Schinkel 2017). The Rotterdam Code, however, especially focuses on "citizens with an immigrant background' often called 'allochthons'.

To contextualize this text, we need to look at the changing mentalities of governing and the changing political situation in the Netherlands which influenced national and local policies on integration and citizenship. Since the 1990s the political climate in the Netherlands changed rapidly. The new phase can be called 'culturistic' and it is expected of immigrants to assimilate in the Dutch/Rotterdam community. The 'culturistic' discourse has culture at the centre of its focus and can be described by the following characteristics: (1) it distinguishes between a 'dominant culture' and 'an-other culture'; (2) it consists of an essentialist way of thinking, framing culture as a stable and determining set of norms and values; (3) it focuses on problems whereby the problems are allocated the 'other culture' which is seen as incompatible with the culture of the 'dominant community' (Schinkel 2017). The 'culturistic' perspective underlying the Rotterdam Code locks into a broader communitarian mentality of governing, stressing conformity to the dominant culture understood in terms of homogeneity, communality and the duty to conform to the dominant norms and values at risk of stigmatization, exclusion, discipline and punishment (cf. Driver and Martell 1997). The norms of the real society ('the culture of the dominant community') are clearly described resembling Dutch norms and values. 'Dutchness' is claimed as 'being enlightened'; thereby paradoxically claiming the Enlightenment as its most valued tradition. Immigrants are seen as the 'other' having a backward and problematic culture. Therefore they are not real citizens because they are not participating in the real society. The only way an immigrant can become a citizen is when she/he integrates (assimilates) into the proper Dutch community.

The coming together of neoliberalism and communitarianism is captured by the concept of neoliberal communitarianism. A neoliberal approach based on individual responsibility, market metaphors and market behavior merges with a conformist communitarian approach that is based on homogeneity, nationalist communality and the duty to conform to the specific and dominant Dutch value. In terms of genealogy, the roots of neoliberal communitarianism are very diverse. Like a rhizome, neoliberal communitarianism can be traced back to different times and different places. One line goes back to the German neoliberalism formulated by Röpke in the 1930-1950s (Ordoliberalism: Foucault 2008), others to the literature on reinventing government at the beginning of the 1990s (Osborne and Gaebler 1993), or to the various socio-political analyses and third way programs at the end of the 1990s (Etzioni, Giddens). But, again, neoliberal communitarianism is also primarily a pragmatics of governing, an art of governing (non-intentionally) invented at the level of policy-making, political struggle and compromise, a strategy of governing using tools derived from various political rationalities to bridge distances, visualize 
and talk about problems while at the same time trying to deal with these issues, whether at a European level (e.g., Bieling 2006 uses the notion of communitarian neoliberalism), the national level (Van Houdt et al. 2011) or at the local level of Rotterdam (Van Houdt and Schinkel 2014).

\subsection{Governing Through Citizenship and the Janus-Face of Responsibilization: Lumping and Splitting}

Before the new (local) coalition was installed in 2002, however, some major disagreements and distrust between the parties had to be brushed away. Liveable Rotterdam was a newcomer and its tough rhetoric on the governing of urban problems, its suspicion of (immigrant) citizens in relation to its harsh stance on crime and safety was viewed with suspicion by both liberals (VVD) and Christian democrats (CDA) (see also Dekker and Van Breugel). Due to the mediation of policy scientist Van Schendelen the parties were brought together. In his role of political broker ['informateur'] Van Schendelen proposed to use the concept of citizenship as the leading theme of the new coalition programme (Van Schendelen 2004). This was because citizenship allowed for both a tough approach of citizens (stressing their duties and responsibilities) as well as stressing their rights (Van Schendelen 2004: 261). Thus, citizenship functioned as a political bridge, and, at the same time, citizenship was introduced as the major technique of governing various populations.

For some decades now, citizenship has been of renewed interest both in scholarly discussions and in political debates (cf. Kymlicka and Norman 1994; Van Gunsteren 1998; Shafir 1998; Isin and Wood 1999; Van Houdt and Schinkel 2009). Studies of governmentality regard citizenship as a technique of governing, while distancing themselves from attempts to naturalize, 'dehistoricize', and universalize these discursive and non-discursive techniques of governing (Van Houdt 2014). Thus citizenship can be regarded as a crucial technique of lumping and splitting populations (to paraphrase Zerubavel 1996) and of attributing responsibilities (Van Houdt 2014). For example, citizenship is a crucial technique in the international management of populations because it splits the global population into subpopulations while lumping citizens together in a nation that is attributed to a state (Hindess 2000). It is typical of the modern discourse to naturalize such a distinction. A governmentality perspective, however, allows the study of the techniques and working of these forms of power (including symbolic violence), including the related inequalities and immobilization of the poor that follows from this modern strategy of divide et impera (Hindess 2000).

Moreover, by using adjectives such as 'good', 'active' and 'responsible', citizenship can be used to differentiate a population internally (Van Houdt 2014). It then functions as a binary code splitting a population into good/bad, moral/immoral, and active/passive citizens and lumping them together in 'society' and its negative other 
'outside society'. These categories are then targeted by different projects of intervention, such as the Rotterdam Code. Programs of self-government are primarily targeted at the virtuous citizenry, regarded to be properly socialized/disciplined and considered economically productive, politically loyal and emotionally attached, while those who are seen as lacking, that is, those who are lumped together as the bad, immoral and passive citizenry, are to be rehabilitated, integrated, educated or they have to remain outside society (considered enemies, threats, 'not integrated') (cf. Schinkel 2017).

Three images of the citizen can be discerned from the local policy documents (see Van Houdt and Schinkel 2014; Schinkel and Van Houdt 2010; cf. Dekker and Van Breugel). The first image is that of the active or responsible citizen. Local policy makers invented "The Technique of Active Citizenship" [Methodiek Actief Burgerschap: Rotterdam City Council 2009] to mobilize this type of citizens into a governing network. As described above, active citizenship is supported by both neoliberalism and communitarianism. Governing through active citizenship entails both a neoliberal emphasis on individual responsibility and a communitarian emphasis on morality, loyalty and duty to the community. Active citizenship is a crucial image that is correlated to the technique of responsibilization. The governing technique of responsibilization aims at making individual citizens, the private sector or communities (at various levels such as families, neighbourhoods or nations) responsible for public tasks previously considered the sole responsibility of the state: i.e., making non-state actors responsible for the governing of crime, social security, the labour market or economy at large, immigrant integration, health care etcetera (Burchell 1993; cf. Schinkel and Van Houdt: 698). In this local case, for example, it means that 'allochtonous citizens' are made responsible for their own civic integration. Responsibilization is thus a crucial technique that is used, on the one hand, to absolve or free the state from previous responsibilities, and, on the other, to forge new private-public partnerships thereby facilitating the co-productions of public services and a governing-at-a-distance. This can be called 'facilitative responsibilization' which assumes a pre-existing autonomous citizen, properly socialized only to be mobilized and called into active service.

However, what also becomes visible in Rotterdam is a second image correlated to another form of responsibilization. Stressing active citizenship coincidentally produces its negative other: the passive, immoral, irresponsible, inactive citizen targeted by repressive (correctional or disciplinary) interventions. This can be called 'repressive responsibilization'. For example, in 2009 the Rotterdam City Council explicitly answered the question what to do when active citizenship and the conditions for self-help, autonomy and responsibility (hence facilitative responsibilization) are lacking:

If the context of active citizenship is not present, for example because people are dealing with social or physical problems or because an area has to be re-conquered, then other tactics are necessary (intervention teams, hot spots, city marines etc.). (Rotterdam City Council 2009: 26) 
This illustrates what we have called the Janus-face of responsibilization: on the one hand facilitative responsibilization geared towards responsible and active citizens, and, on the other hand, repressive responsibilization targeting irresponsible/inactive citizens (Schinkel and Van Houdt 2010: 708-10).

The Rotterdam municipality uses several ways of dealing with 'irresponsibility' and working towards responsible and active citizenship. For example, one of these interventions is called the Early Intervention in Families (EIF: 'Vroegtijdige Interventie in Gezinnen': Rotterdam City Council 2006a, b). The EIF tries 'to intervene in a multi-problem family as early as possible, based on signals out of the field, and to learn parents to take responsibility for their children and to integrate in society' (Rotterdam City Council 2006b: (1). The aim of EIF is to educate responsibility, to prevent crime and nuisance and to better chances on the job market (Rotterdam City Council 2006b: (2). A 'family coach' is allocated to the family for $24 \mathrm{~h}$ a day, 7 days a week and aims at teaching 'responsibility', ensuring that the parents follow language courses and sending children (back) to school (Rotterdam City Council 2006a, b: 2). In contrast to governing-at a distance (facilitative responsibilization), repressive responsibilization is thus typical of governing-at-close-range in the homes, souls, bodies and brains ${ }^{3}$ of citizen subjects (for 'early detection' of problems is said to begin when the baby is still in its mother's womb) (Schinkel and Van Houdt 2010). It occurs when citizens who are deemed risky are constructed as in need of and sensitive or responsive to disciplinary interventions.

In sum, facilitative responsibilization takes place for instance where communities are mobilized to counter crime because a high victimization risk exists and repressive responsibilization occurs where it is citizens themselves who are deemed risky and 'in need of disciplinary interventions'. However, the diagram of emergency also invented a third citizen image: the high risk citizen. The latter category consists of those to whom neither facilitative nor repressive responsibilization is geared, but who are targeted by techniques related to the sovereign technology of power (e.g., punishment, banishment, prohibition). This type of citizen is considered to be beyond correction (discipline) while representing a threat to persons and goods. Following on from the logic of emergency (tough times demand tough measures), a new intervention was invented: the Frequent Offender Institution [Instelling

\footnotetext{
${ }^{3}$ Our previous work also shows that the overall problematization of (super) diversity in terms of problems of 'integration' and 'crime and safety' locks into a general movement away from a focus on larger macro-structures and sociological accounts of social problems towards more micro-oriented and biological approaches (e.g. Van Houdt and Schinkel 2013). In the context of the rise of the new life sciences (e.g. neuroscience) and in relation to the problematization of super diversity, it can be argued that the brain will become the new site of knowledge, intervention and subjectification. The larger neuroscientific movement helps to strengthen a particular focus on the deviant (migrant, criminal) body by prioritizing the brain. This can be called "neurogovernmentality": a novel way of governing social problems in relation to knowledge, products and technologies produced by neuroscience. This will be further scrutinized by one of the authors (Van Houdt) in the next years.
} 
Stelselmatige Dader]. ${ }^{4}$ This is a total institution aimed at the incarceration of the so called 'frequent offenders' (see Van Houdt and Schinkel 2014). The high risk citizen is 'selectively incapacitated' and hence exempted from the larger community.

This leads then not to two images of the citizen but to a threefold differentiation between: (1) the active citizen; (2) the low risk citizen; (3) the high risk citizen. This three-tiered hierarchy of governing images of citizens, we argue, signals crucial shifts in the self-reflection of government as it increasingly moves away from a rationality based on conceptions of welfare. Again, as was the case with active citizenship, though based on a different logic, both neoliberalism and communitarianism support the same technique of governing (now selective incapacitation), which is legitimated, on the one hand, to defend the market, and, on the other, to defend the community.

\subsection{Conclusion: Beyond Exceptionalism?}

Based on the recurring diagram of 'laboratory exceptionalism', the city of Rotterdam has, over the last couple of decades, observed itself (again) as on the verge of collapse and cleared the ground by inventing a new formulae of governing the city and its populations. As Van den Berg $(2012,2013)$ shows, Rotterdam aims at transforming into a more feminine and post-industrial city. However, this involves a particular femininity. Not so much or solely a social bosom of (welfarist) care but a complex combination of a moralizing finger and a sovereign fist targeting a diverse and primarily coloured under-class, and the welcoming of the proper creativity and diversity of what can be called a 'yupper class'. In recent years, this has been accompanied with a city marketing campaign that has been enormously successful in, perhaps for the first time in many decades, putting forth a positive image of Rotterdam as a vibrant tourist destination characterized by contemporary architecture. Here, the clearing of the ground becomes positively coded: because the ground has been cleared, Rotterdam has lots of exciting architecture. The result of this marketing campaign, which consisted partly of city officials pampering international journalist and giving them tours through parts of the city, has been that Rotterdam has been given positive attention in international fora. Moreover, Rotterdam was listed as a top 10 destination in 2014 by The New York Times ${ }^{5}$ and it was praised by the 'Rough Guide', ${ }^{6}$ Lonely Planet ${ }^{7}$ and The Guardian.

\footnotetext{
${ }^{4}$ The 'Frequent Offenders Institution Order' ('FOIO', 'ISD': 'Instelling Stelselmatige daders') is active since 2004. The practical object (a 'frequent offender') is: (1) (s)he who committed a serious crime; (2) a person convicted in the last 5 years for at least three other crimes; (3) a serious threat for the safety of persons and goods (Struijk 2007: 350-354). The primary goal of measures aimed at such persons is 'social defence' (art. $38 \mathrm{~m}$ sub $2 \mathrm{Sr}$; cf. Struijk 2007: 353).

${ }^{5}$ http://www.nytimes.com/interactive/2014/01/10/travel/2014-places-to-go.html?_r=0

${ }^{6} \mathrm{http}: / / \mathrm{www} \cdot$ roughguides.com/? $\mathrm{s}=$ rotterdam $\& \mathrm{x}=0 \& \mathrm{y}=0$

${ }^{7} \mathrm{http}: / /$ www.lonelyplanet.com/best-in-travel/cities/5
} 
The question is: does this signal a shift in the governing of the Rotterdam population? Perhaps, in part, it does. At least the figure of the exception seems to be invoked less in the most recent period (though the logic of exception is still used, now under the radar, and still with success by policy lobbyists). But that is partly because previous efforts at problematizing the Rotterdam population may have been successful, as have efforts at keeping certain people out of the city or out of specific neighbourhoods by means of the 'Umbrella and Exception Law'. In exchange, the city has been competing, in typical neoliberal fashion, in a game of interurban competition very much driven by what has been called 'imagineering the city' (Van den Berg 2015). But the link with neoliberal communitarianism and urban branding has been there all along. As Marguerite van den Berg has argued (2012) the city has been in the process of changing from a rough image to a more polished, feminine image. At the same time, the problematization of the poor has been a way to emphasize that Rotterdam needed more 'middle-class' people. In that sense, changing the population $i s$ changing the image of the city, as the desired 'middle-class', which is actually an 'upper' middle-class, deploys a different aesthetic taste. It is more compatible with a city centre as a 'city lounge', with loitering without nuisance. So, questions of urban community, and efforts at shaping it in very particular ways, have been folded into neoliberal city marketing efforts for some time. At least for the time being, the international success of Rotterdam as an urban image has curtailed the need to emphasize how exceptionally bad the situation in the city is. But it is too early to conclude that a 'yupper class' has permanently displaced populations less suited for the neoliberal communitarian project. Certainly, the authoritative tourist guides won't list Rotterdam as top destination every year. So perhaps the current celebration of the city will turn out to be yet another experiment on the way to new emergencies.

\section{References}

Agamben, G. (1998). Homo Sacer. Sovereign power and bare life. Stanford: Stanford University Press.

Bieling, H. J. (2006). Neo-liberalism and communitarianism: Social conditions, discourses and politics. In D. Plehwe, B. Walpen, \& G. Neunhoffer (Eds.), Neoliberal hegemony: A global critique (pp. 207-221). London: Routledge.

Brown, W. (2006). American nightmare: Neoliberalism, neoconservatism, and de-democratization. Political Theory, 34(6), 690-714.

Burchell, G. (1993). Liberal government and techniques of the self. Economy and Society, 22(3), 267-282.

Bureau Binnenstad Gemeente Rotterdam. (2008). Binnenstad als City lounge. Binnenstadsplan 2008-2030. Rotterdam: Rotterdam Municipality.

Chatterjee, P. (2004). The politics of the governed. Reflections on popular politics in most of the world. New York: Columbia University Press.

Dean, M. (2010). Governmentality: Power and rule in modern societies (2nd ed.). London: Sage.

Delanty, G. (2002). Communitarianism and citizenship. In E. Isin \& B. Turner (Eds.), Handbook of citizenship studies (pp. 159-174). London: Sage Publications. 
Driver, S., \& Martell, L. (1997). New labour's communitarianism. Critical Social Policy, 17, $27-46$.

Easterling, K. (2014). Extrastatecraft: The power of infrastructure space. London: Verso.

Foucault, M. (2008). The birth of bio-politics. Lectures at the Collège de France, 1978-1979. Basingstoke. New York: Palgrave Macmillan.

Gemeente Rotterdam. (2007). Stadsvisie Rotterdam. Ruimtelijke ontwikkelingsstrategie 2030. Rotterdam: Rotterdam Municipality.

Gieryn, T. F. (2006). City as truth-spot: Laboratories and field-sites in urban studies. Social Studies of Science, 36(1), 5-38.

Halpern, O., LeCavalier, J., Calvillo, N., \& Pietsch, W. (2013). Test-bed urbanism. Public Culture, 25(2), 272-306.

Hindess, B. (2000). Citizenship in the international management of populations. American Behavioral Scientist, 43, 1486-1497.

Isin, E. F., \& Wood, P. K. (1999). Citizenship and identity. London: Sage.

Kymlicka, W., \& Norman, W. (1994). Return of the citizen: A survey of recent work on citizenship theory. Ethics, 104(2), 352-381.

Noordegraaf, M. (2008). Meanings of measurement. The real story behind the Rotterdam safety index. Public Management Review, 10(2), 219-237.

Notten, T. (Ed.). (2008). De lerende stad: Het laboratorium Rotterdam. Apeldoorn: Garant.

Ong, A. (2006). Neoliberalism as exception: Mutations in citizenship and sovereignty. Durham: Duke University Press.

Osborne, D., \& Gaebler, T. (1993). Reinventing government: How the entrepreneurial spirit is transforming the public sector. New York: Penguin.

Rooijendijk, C. (2005). Urban ideal images in post-war Rotterdam. Planning Perspectives, 20(2), 177-209.

Rose, N. (2000). Community, citizenship, and the third way. American Behavioral Scientist, 43(9), $1395-1411$.

Rotterdam Ombudsman. (2007). Baas in eigen huis. "Tja, wij komen eigenlijk voor alles." Rapport van een ambtshalve onderzoek naar de praktijk van huisbezoeken. Rotterdam: Ombudsman Rotterdam.

Schinkel, W. (2017). Imagined societies. In A Critique of Immigrant Integration in Western Europe. Cambridge: Cambridge University Press.

Schinkel, W., \& van den Berg, M. A. (2011). City of exception: The Dutch revanchist city and the urban Homo Sacer. Antipode, 43(5), 1911-1938.

Schinkel, W., \& Van Houdt, F. (2010a). The double helix of cultural assimilationism and neoliberalism: Citizenship in contemporary governmentality. The British Journal of Sociology, 61(4), 696-715.

Schinkel, W., \& van Houdt, F. (2010b). Besturen door vrijheid: Neoliberaal communitarisme en de verantwoordelijke burger. Bestuurskunde, 2, 12-21.

Schuyt, C. J. M., \& Taverne, E. (2000). 1950. Welvaart in zwart-wit. The Hague: Sdu Uitgevers.

Shafir, G. (Ed.). (1998). The citizenship debates. A reader. Minneapolis: University of Minnesota Press.

Struijk, S. (2007). Rechtshandhaving en Veelplegers; Ontwikkeling van Drang naar Dwang. In J. Blad (Ed.), Strafrechtelijke Rechtshandhaving (pp. 343-368). Den Haag: Boom Juridische Uitgevers.

Tops, P. (2011). Regimeverandering in Rotterdam. Hoe een stadsbestuur zichzelf opnieuw uitvond. Amsterdam: Atlas.

Uitermark, J., \& Duyvendak, J. W. A. (2006). Sociale integratie ... straataanpak in de praktijk. In Essay Mensen Maken de Stad: Ruimte maken voor burgerschap. Amsterdam: Amsterdam University Press.

Uitermark, J., \& Duyvendak, J. W. (2008). Civilising the city: Populism and revanchist urbanism in Rotterdam. Urban Studies, 45(7), 1485-1503. 
van den Berg, M. A. (2012). Femininity as a city marketing strategy: Gender bending Rotterdam. Urban Studies, 49(1), 153-168.

van den Berg, M. A. (2013). Mothering the post-industrial city: Family and gender in urban regeneration. University of Amsterdam Dissertation, Amsterdam.

van den Berg, M. (2015). Imagineering the city. In R. Paddison \& T. Hutton (Eds.), Cities \& economic change: Restructuring and dislocation in the global metropolis (pp. 162-175). London: Sage.

van der Woud, A. (2010). Koninkrijk vol sloppen. Achterbuurten en vuil in de negentiende eeuw. Amsterdam: Bert Bakker.

van Eijk, G. (2010). Exclusionary policies are not just about the 'neoliberal city': A critique of theories of urban revanchism and the case of Rotterdam. International Journal of Urban and Regional Research, 34(4), 820-834.

van Gunsteren, H. R. (1998). A theory of citizenship. Organizing plurality in contemporary societies. Boulder: Westview Press.

van Houdt, F. (2014). Governing citizens - The government of citizenship, crime and migration in the Netherlands (Dissertation). Rotterdam: Ersmus Universfzity Rotterdam.

van Houdt, F., \& Schinkel, W. (2009). Aspecten van Burgerschap: een historische analyse van de transformaties van het burgerschapsconcept in Nederland. Beleid en Maatschappij, 1, 50-58.

van Houdt, F., \& Schinkel, W. (2013). A genealogy of neoliberal communitarianism. Theoretical Criminology, 17(4), 493-516.

van Houdt, F., \& Schinkel, W. (2014). Crime, citizenship and community: Neoliberal communitarian images of governmentality. The Sociological Review, 62(1), 47-67.

van Houdt, F., Suvarierol, S., \& Schinkel, W. (2011). Neoliberal communitarian citizenship - Current trends towards 'earned citizenship' in the United Kingdom, France, and the Netherlands. International Sociology, 26(3), 408-432.

van Schendelen, R. (2004). Katholieke of Protestantse Coalitievorming? De Formatie van het Rotterdamse college in 2002. Documentatiecentrum Nederlandse Politieke Partijen Jaarboek 2003-2004: 249-273.

van Swaaningen, R. (2008). Sweeping the street: Civil society and community safety in Rotterdam. In J. Shapland (Ed.), Justice, community and civil society: A contested terrain (pp. 87-106). Devon: Willan Publishing.

van Traa, C. (1946). Het nieuwe hart van Rotterdam. Toelichting op het Basisplan voor den herbouw van de binnenstad van Rotterdam. Rotterdam: Nijgh \& van Ditmar.

van Ulzen, P. (2007). Imagine a metropolis. Rotterdam's creative class, 1970-2000. Rotterdam: 010 Publishers.

Wacquant, L. (2009). Prisons of poverty. Minneapolis: University of Minnesota Press.

Wagenaar, C. (1992). Welvaartsstad in wording. In De wederopbouw van Rotterdam 1940-1952. Rotterdam: NAi Uitgevers.

Zerubavel, E. (1996). Lumping and splitting: Notes on social classification. Sociological Forum, 11(3), 421-433.

\section{Local Policy Documents}

Rotterdam City Council. (2002). Het Nieuwe Elan van Rotterdam ['The New Elan of Rotterdam' Policy Program]. Rotterdam: City Council.

Rotterdam City Council. (2003). Rotterdam zet door: op weg naar een stad in balans. Rotterdam: City Council. 
Rotterdam City Council. (2006a). Samen werken aan veiligheid: voorkomen en handhaven'. Vijfjarenactieprogramma veilig Rotterdam 2006-2010 ['Working together towards safety: Prevention and enforcement'. Five year action program safe Rotterdam 2006-2010']. Rotterdam: City Council.

Rotterdam City Council. (2006b). Vroegtijdige Interventie Gezinnen [Early intervention in families]. Rotterdam: City Council (Security and Safety Directorate).

Rotterdam City Council. (2009). Werken aan een veiliger Rotterdam, de aanpak. Methodiek actief burgerschap [Technique of active citizenship]. Rotterdam: City Council (Security and Safety Directorate).

Open Access This chapter is licensed under the terms of the Creative Commons Attribution 4.0 International License (http://creativecommons.org/licenses/by/4.0/), which permits use, sharing, adaptation, distribution and reproduction in any medium or format, as long as you give appropriate credit to the original author(s) and the source, provide a link to the Creative Commons license and indicate if changes were made.

The images or other third party material in this chapter are included in the chapter's Creative Commons license, unless indicated otherwise in a credit line to the material. If material is not included in the chapter's Creative Commons license and your intended use is not permitted by statutory regulation or exceeds the permitted use, you will need to obtain permission directly from the copyright holder.

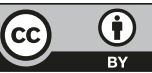

